КОНСТИТУЦІЙНИЙ РОЗВИТОК КАНАДИ

\title{
CONSTITUTIONAL DEVELOPMENT OF CANADA
}

\author{
Уколова В.О., студентка III курсу \\ міжнародно-правового факультету \\ Національний юридичний університет імені Ярослава Мудрого
}

Уколова Є.О., студентка III курсу Інститут підготовки кадрів для органів юстииії України Національного юридичного університету імені Ярослава Мудрого

Стаття присвячена питанню конституційного розвитку Канади починаючи з моменту прийняття Конституції 1982 р. та сучасного стану. Метою статті є окреслення основних аспектів еволюції канадської Конституції 1982 р., а саме: подій, які передували прийняттю Конституції, процесу розробки та прийняття, структурних особливостей, впливу Верховного Суду, ролі провінцій у конституційному розвитку держави.

Було констатовано, що формування британської Канади розпочалося з 1763 р., коли було укладено Паризький мирний договір, за яким Франція передала територію Канади під контроль Англії. Британський парламент видав Акт про Британську Північну Америку 1867 р., який проголошував створення канадської федерації у статусі домініону Великобританії. Встановлено, що до 1867 р. провінції не відігравали ролі в процедурі внесення змін до законопроєктів. 3 прийняттям Акта про Британську Північну Америку провінціями вони почали брати участь у схваленні поправок. Ця практика створила важливий прецедент - «конституційне питання». Верховний Суд було визначено як орган, що здійснює тлумачення законодавства, консультує уряди з важливих питань права. Зокрема, роль Верховного Суду у конституційному розвитку яскраво продемонстрована в рішенні про конституційну репатріацію (1981р.). У статті визначена особливість форми Конституції, яка поєднує в собі писану та неписану. До складу писаної належать: канадські та британські законодавчі акти прокламації Корони і Генерал-губернатора Канади, накази у Раді, міжнародні нормативні акти, прийняті у рамках Британської Співдружності. Неписаний складник представлений конституційними угодами та правовими звичаями.

У статті відзначено, що Конституція Канади 1982 р. закріпила у собі новелу, яка полягає у введенні інституту внесення поправок, що здійснюється без участі британського парламенту. Для вчинення такої процедури необхідною є ініціатива з боку Сенату, Палати громад або законодавчих зборів будь-якої провінції. Було досліджено, що після прийняття Конституції 1982 р. у провінціях було видано акти, які являють собою конституційні реформи (Акт про швидке вирішення конституційних та інших провінційних питань від 1989 р. та інші). Зроблено висновок про те, що прийняттю Конституції 1982 р. передувала активна діяльність державних органів, пов'язана із виданням нормативних актів, деякі з яких згодом стали її складниками.

Ключові слова: Конституція, домініон, федерація, Канада, репатріація, Конституційний акт, Верховний Суд, провінція, незалежність, поправки, реформа.

The article is devoted to the disclosure of the issue of Canada's constitutional development with the subsequent adoption of the 1982 Constitution and a review of current reforms to it. Its purpose is to analyze the main aspects of the evolution and formation of the Canadian Constitution of 1982, namely: the events that preceded the adoption of the Constitution, the process of its development and proclamation, structural features, the influence of the Supreme Court and the role of provinces in constitutional development.

It was stated that the formation of British Canada began in 1763, when the Treaty of Paris was concluded, under which France transferred Canadian territory to British control. The British Parliament issued the British North America Act of 1867, which proclaimed the creation of a Canadian federation as the dominion of Great Britain. It was established that until 1867 the provinces did not play a role in the process of amending the bills, but with the adoption of the Act of British North America it was amended and approved by the provinces. This practice set a precedent. The Supreme Court has been identified as a body that interprets legislation and advises governments on important legal issues. The role of the Supreme Court in constitutional development is clearly evident in the 1981 decision on constitutional repatriation.

Attention is paid to the form of the Constitution, which combines written and unwritten. The writing includes: Canadian and British legislation, proclamations of the Crown and Governor-General of Canada, orders in the Council, international regulations adopted within the British Commonwealth. The unwritten component is represented by constitutional agreements and legal customs. It is noted that the Constitution of Canada in 1982 enshrined a novelty, which is to introduce the institution of amendment, which is carried out without the participation of the British Parliament. Such a procedure requires the initiative of the Senate, the House of Commons or the legislature of any province. It was investigated that after the adoption of the 1982 Constitution, acts were issued in the provinces that constitute constitutional reforms (the Act on the Rapid Resolution of Constitutional and Other Provincial Issues of 1989 and others). It is concluded that the adoption of the 1982 Constitution was preceded by a number of historical events, the active work of government agencies associated with the issuance of regulations, some of which later became part of it.

Key words: Constitution, dominion, federation, Canada, repatriation, Constitutional Act, Supreme Court, province, independence, amendments, reform.

Постановка проблеми. Із піднесенням демократичних начал поширилась думка, що закони мають відображати саме суспільні інтереси, а не конкретні особисті інтереси законодавців. Інакше кажучи, аби акти набували форми та суті законів в умовах демократії, вони мають відповідати таким критеріям, як передбачуваність та поширення на всіх осіб без винятку. Варто вказати, що нині Канада $\epsilon$ однією із найвідоміших, досить розвинутих у багатьох сферах життєдіяльності країн, особливо у соціально-економічному плані. Це - демократична федерація, яка забезпечила достатній рівень життя та благополуччя для своїх громадян, незважаючи на той факт, що країна пройшла довгий та важкий шлях до фактичної незалежності.

Протягом періоду становлення Канади як самостійної держави Конституція 1982 р. увібрала у себе всі зна- чимі ідеї, положення правового, соціального, політичного характеру, які стали віддзеркаленням певних етапів істоpiї канадської федерації. Значний вплив на формування як держави, так і Конституції справило Сполучене Королівство Великої Британії і Північної Ірландії (далі - Сполучене Королівство), оскільки Канада була ії колонією і $є$ домініоном. Таким чином, канадська Конституція є унікальним та різноплановим об'єктом наукових досліджень у наш час, оскільки можна більш детально ознайомитися iз регулюванням статусу людини і громадянина, органів державної влади, порядком внесення змін до неї тощо.

Метою роботи $є$ розкриття етапів еволюції канадської Конституції 1982 р., а саме: подій, які передували прийняттю Конституції, процесу іiї розробки та затвердження, визначення структурних і змістових особливостей. 
Аналіз наукових публікацій. Питанням конституційного розвитку канадської федерації займалося багато зарубіжних науковців, серед яких можна виокремити: П. Рассела [2], П. Хогга [3], Г. Реммілара [4], Дж.Л. Галла, К. Макіна, Г. Лісона [5], С.Ю. Данилова, С.П. Сімаєву, А.М. Муртазина, Г. Трамбле та інших.

Виклад основного матеріалу. Історія формування британської Канади бере початок з 1763 р., коли було укладено Паризький мирний договір, який поклав кінець Семирічній війні та за яким Франція передала територію Канади під контроль Англії. Конституційною основою для Канади стала Королівська прокламація «Про формування колонії Квебек», яка була оприлюднена 7 жовтня 1763 р. королем Георгом III. Вона стала необхідним інструментом придушення спроб боротьби за незалежність, які здійснювалися жителями 13 колоній Північної Америки. Також відповідно до їі положень на території провінції запроваджувалося британське законодавство, офіційною мовою ставала англійська, незважаючи на те, що майже все населення було французами, надавалася свобода віросповідання для католиків, проте водночас вони були позбавлені політичних прав. У такий спосіб британська Корона прагнула здійснити асиміляцію франкомовного населення Канади, але це лише призвело до масового невдоволення в новій колонії. Переломним моментом для Канади стало прийняття у 1867 р. Акта про Британську Північну Америку (з 1982 р. - Конституційний акт 1867 р.) (далі - Акт 1867 р.). Цей акт проголошував створення канадської федерації у статусі домініону Великої Британії у складі таких північноамериканських провінцій, як Канада, Нова Шотландія та Нью-Брансвік. Такий статус надавав певний обсяг самостійності у вирішенні внутрішніх справ.

Характерною ознакою державного устрою Канади стало запровадження Вестмінстерської системи, яка притаманна і Великій Британії. У преамбулі Акта 1867 р. вказується: «Беручи до уваги, що провінції Канада, Нова Шотландія і Нью-Брансвік висловили бажання об'єднатися в єдиний Домініон під Короною Сполученого Королівства Великої Британії та Ірландії з Конституцією, в принципах подібної до Конституції Сполученого королівства» [1]. Проте принципи британського конституціоналізму не були закріплені в писаній частині конституції. Дослідивши це питання, можна побачити, що такі принципи містяться в різних конвенціях, традиціях та практиці, які 3 часом змінюються, але залишаються актуальними для застосування.

Важливо вказати, що саме Вестмінстерська система, котра притаманна британській монархії, стала фундаментом для державної системи Канади. За формою правління канадська федерація визначалася конституційною монархією, де главою $є$ монарх Сполученого Королівства. Особливістю було те, що представником Корони на території Канади став Генерал-губернатор, який призначається першим та формує третю складову частину уряду - Таємну раду Канади. Здебільшого виконавча влада представлена у вигляді Кабінету, який є частиною Таємної ради і очолюється Прем'єр-міністром (лідером партії, яка отримала більшість місць після виборів Палати громад). Кажучи про Парламент, треба підкреслити, що за структурою він є трикомпонентним, де верхня палата Сенат, нижня - Палата громад, а також до нього входить i Корона. Наявність саме такого складу законодавчого органу говорить про те, що монарх має повноваження, яке полягає у промульгації законів після їх попереднього спільного прийняття двома палатами парламенту. Найвищим органом судової влади є Верховний Суд Канади.

Досліджуючи Акт 1867 р., можна виокремити такі принципи судової влади в канадській конституційній системі, як незалежність судової влади, білінгвізм, бікультуризм і федералізм. Перший принцип стосується відправлення правосуддя, а два інших - основних прав і системи правління в Канаді. Разом із тим, як стверджує англійський науковець П. Рассел, конституційні положення, що стосуються судової системи, не можуть оцінюватися виключно з точки зору їх впливу на здійснення правосуддя [2, с. 104]. Також можна стверджувати, що Канаді притаманний централізований характер управління регіонами. Це насамперед проявляється у втручанні Генерал-губернатора в діяльність інших гілок влади, а федеральних органів - у справи провінцій.

Треба звернути увагу на те, що після прийняття Вестмінстерського статуту 1931 р. (далі - Статут 1931 р.) до Акта 1867 р. зміни вносились лише британським Парламентом. Однак це не означало, що цей процес залишався поза контролем Канади. У 1930 р. було проведено конференцію, на якій також було узгоджено конституційну «конвенцію» про те, що Парламент Великої Британії не буде вносити поправки до Акта 1867 р. без згоди Канади. До речі, ця конвенція не передбачала компетенцію органів Канади щодо подання запиту згоди. Тому ще до 1930 р. у Канаді склалася практика подавати запити на поправки «спільним зверненням» Палати громад і Сенату Канади. Запит мав складатися з резолюції, яка містила вимогу до уряду Великої Британії внести до британського парламенту законопроєкт про внесення поправок та його тексту. У разі, якщо спільне звернення подавалося двома палатами парламенту, воно надсилалося Генерал-губернатором уряду Великої Британії.

До речі, провінції не брали участі в описаному процесі. Більше того, федеральним урядом не було вироблено послідовної практики отримання згоди провінцій перед поданням запиту на внесення змін. 3 моменту введення Акта 1867 р. в дію до нього було внесено 15 поправок. Лише 4 iз них (1940 р., 1951 р., 1960 р., 1964 р.) були одностайно схвалені провінціями. Щодо поправки 1907 р., то їй передували консультації з провінціями (Британська Колумбія виступила проти неї). Решта десять поправок були витребувані спільним зверненням Парламенту Канади і прийняті британським Парламентом без попередніх консультацій з провінціями. Тим не менше, більшість прем'єр-міністрів Канади заявляли, що не слід розпочинати процедуру внесення змін, поки не отримано одностайної згоди провінцій. Підставою для таких вимог став прецедент, встановлений 4 поправками, яким передувала одностайна згода провінцій. Три з цих поправок перенесли законодавчу владу з провінційних законодавчих органів на федеральний Парламент. Завдяки цим поправкам змінився розподіл законодавчих повноважень між федеральним Парламентом та провінційними законодавчими органами [3, с. 291]. Також протягом століття Акт 1867 р. підлягав внесенню до нього поправок, які стосувалися зміни кордонів канадської федерації, у результаті чого всі британські колонії в Північній Америці були інтегровані в їі склад. Крім того, зміни торкалися роз'єднання повноважень між канадським домініоном і англійською метрополією.

Значимою подією для Канади стало прийняття парламентом 8 квітня 1875 р. за ініціативою ліберального уряду на чолі з Прем'єр-міністром О. Маккензі законопроєкту про створення Верховного Суду. Уряд стверджував, що це $є$ необхідним для стандартизації канадського законодавства та надання тлумачення конституційних положень. Згідно із законопроєктом, Верховний Суд не тільки мав оголошувати рішення, консультувати федеральний та провінційний уряди 3 важливих питань права, висловлювати думки щодо конституційності, тлумачення федерального чи провінційного законодавства, повноважень Парламенту та законодавчих органів провінцій. Найвідомішим і найважливішим з рішень Верховного Суду стало рішення про конституційну репатріацію [4].

Все почалося з того, що Прем'єр-міністр П. Трюдо зробив спробу «репатріації» («повернення на Батьківщину») і зміни Конституції. Суть репатріації полягала в тому, що 
вона мала супроводжуватися включенням до тексту Конституції процедури внесення змін, яка дозволила б змінити Конституцію без звернення до британського Парламенту. Проте наслідок такої спроби проявився у тому, що Оттава та два іï союзники (провінції Онтаріо та НьюБрансвік) зіткнулися з вісьмома іншими провінціями. Вони ввійшли в історію як «Банда восьми». Провідне місце в цій дискусії посідало питання про те, чи потрібна згода провінцій для внесення змін до Конституції, які зачіпали б права, привілеї або повноваження провінцій. У 1981 р. Уряд П. Трюдо звернувся до Верховного Суду з проханням вирішити питання про те, чи може Оттава діяти самостійно, щоб внести зміни до Конституції. 7 із 9 суддів вважали, що Парламент мав законне право діяти в односторонньому порядку. Але з другого питання 6 із 9 суддів визнали, що односторонні федеральні дії, без суттєвої підтримки провінцією змін до конституції, суперечать давній конвенції. Як наслідок, Верховний Суд ухвалив рішення про те, що Оттава має юридичне право в односторонньому порядку вимагати внесення поправки через британський Парламент. Верховний Суд також постановив, що, згідно з домовленістю, було б неприпустимо це робити без «консенсусу» провінцій. Врешті-решт, ні Оттава, ні незгодні провінції не отримали бажаного рішення суду для себе [5]. Для опонентів постала необхідність у досягненні компромісу. Усі сторони, за винятком Квебека, досягли угоди 5 листопада 1981 р. Представники Квебека наголошували, що відповідно до принципу «подвійності» для внесення основних конституційних змін необхідна згода як англомовної, так і франкомовної Канади, і що відсутність хоча б однієї з них призведе до заборони такої угоди. Але інші провінції заперечували існування принципу «подвійності».

Незважаючи на наявні заперечення, 17 квітня 1982 p. в Оттаві Королева Єлизавета II підписала Конституційний акт, прийнятий британським Парламентом. У Королівській прокламації до цього акта було зазначено, що внаслідок своєї приналежності до суверенної держави канадці мають усю повноту влади змінювати Конституцію Канади [6]. Таким чином, у Канаді одночасно було проголошено незалежність держави та прийняття власної Конституції. Цікавим є той факт, що день незалежності північноамериканська держава святкує 1 липня, тобто з моменту набуття чинності Акта про Британську Північну Америку 1867 р. Того року Сполучене Королівство Великої Британії і Північної Ірландії визнало Канаду своїм домініоном, який має право на самоврядування.

Канадська конституція поєднує у собі такі ознаки: парламентську демократію, федералізм, права і свободи громадян та права корінних жителів. Деколи вони доповнюють одна одну, але частіше перебувають у стані допустимого конфлікту. Варто сказати, що форма конституції канадської федерації поєднує у собі писану і неписану частини. До складу писаної належать: канадські та британські законодавчі акти (наприклад, Акт 1867 р., Конституційний акт 1982 р.), прокламації Корони і Генерал-губернатора Канади, накази у Раді (акти, які видаються від імені монарха і Таємної ради Канади), міжнародні нормативні акти, прийняті у рамках Британської Співдружності (Статут 1931 р., який регулював правове становище домініонів та їх відносини зі Сполученим Королівством). 3 огляду на той факт, що у Канаді діяла система загального права Британії, за якого судові рішення ставали судовими прецедентами, можна стверджувати, що вони діяли на рівні із законодавчими актами. 3 приводу цього 28 вересня 1981 р. Верховний суд Канади постановив, що Конституція складається із норм законів, норм загального права і конституційних конвенцій [7].

Щодо неписаного складника Конституції 1982 р., то вона представлена конституційними угодами та правовими звичаями. Слід наголосити, що перші виникають, як правило, тоді, коли існує тривалий процес державно- політичних відносин. Як приклад, можна говорити про такі конституційні угоди, як: призначення за порадою Прем'єр-міністра міністрів, призначення лідера партії, яка отримала більшість у Палаті громад, на посаду Прем’єр-міністра тощо.

У Конституційному акті 1982 р. (входить до Акта про Канаду 1982 р.) велику роль відіграє Хартія прав і свобод Канади (далі - Хартія), яка замінила Білль про права 1960 р. та вперше на конституційному рівні затвердила основні права і свободи людини та громадянина, однак не передбачає положень щодо обов'язків громадян держави. Хартія проголосила широкий перелік гарантій прав і свобод (свободу совісті, віросповідання, думки), демократичних прав (активне і пасивне виборче право на виборах членів Палати громад), особистих прав (право громадян на пересування), а також перелік судових гарантій (право на життя, право на особисту недоторканність). Особливої уваги заслуговує принцип рівності (п. 15), який встановлює: «Рівність перед законом і на підставі закону, рівний захист і заступництво з боку закону. Закон не робить відмінностей для осіб і рівною мірою застосовується до всіх, і всі мають право на рівний захист і рівне заступництво закону, незалежно від будь-яких відмінностей, зокрема, заснованих на ознаках раси, національного чи етнічного походження, кольору шкіри, релігії, статі, віку або внаслідок психічних або фізичних вад» [8]. А також принцип рівності проявляється у наявності в Хартії норм про визнання офіційними мовами як англійської, так і французької; забезпечення аналогічних прав і привілеїв школам із роздільним навчанням. Правовий статус корінних народів Канади (індійці, метиси та інуїти) закріплений у декількох статтях Конституційного акта 1982 р. за межами Хартії, де встановлено, що їхні права визнаються і підтверджуються.

Конституційний акт 1982 р. закріпив новелу, яка полягає у введенні інституту внесення поправок, що здійснюється без участі британського Парламенту. Для того щоб вчинити таку процедуру, необхідним є прояв ініціативи 3 боку Сенату, Палати громад або законодавчих зборів будь-якої провінції. Відповідно до п. 38 зазначеного Акта встановлюється звичайна процедура внесення поправок до Конституції Канади, яка полягає у такому: «Конституція Канади може бути змінена шляхом видання Генерал-губернатором Прокламації 3 додатком великої печатки Канади, уповноваженого на це: а) резолюціями Сенату і Палати громад; б) резолюціями законодавчих зборів щонайменше двох третин провінцій, населення яких згідно з останнім загальним переписом становить у сукупності щонайменше п'ятдесят відсотків населення всіх провінцій.

Після прийняття Конституції 1982 р. у провінціях було видано чимало актів, які нині становлять практику сучасних конституційних реформ. Так, наприклад, в Акті про швидке вирішення конституційних та інших провінційних питань від 1989 р. (з поправками від 1999 р.) зазначається, що суд провінції Нова Шотландія не може визнати закон недійсним чи непридатним і не надає засобів правового захисту до тих пір, поки Генеральний прокурор не отримає відповідне повідомлення. Якщо у суді провінції під сумнів ставиться чинність прокламації, постанови чи розпорядження Ради, то суд також не може їх визнати нечинними доти, поки Генеральний прокурор провінції не отримає повідомлення. Таке повідомлення має подаватися принаймні за 14 днів до дня вирішення спору. Суд може за клопотанням еx parte розпорядитися про зменшення строку вручення повідомлення [9]. Подібні акти видавалися в провінціях Манітоба, Саскачеван, Онтаріо тощо.

Вітчизняні і зарубіжні науковці відзначають сучасну тенденцію щодо ускладнення процедури проведення конституційної реформи як на федеральному рівні, так і на рівні провінції. Так, на федеральному рівні діс Акт щодо конституційних поправок (1996р.), відповідно до якого 
зміни у порядку п. 38, 41, 43 потребують обов'язкової підтримки провінцій Онтаріо, Квебек, Британської Колумбії, 23 Атлантичних та 2 Степових провінцій. Крім того, парламенти провінцій Альберта та Британська Колумбія прийняли Акти про конституційний референдум, згідно 3 якими лейтенанти-губернатори цих провінцій повноважені виносити на регіональні референдуми проєкти поправок до Конституції Канади до їх обговорення у Законодавчих зборах цих провінцій. Рішення виборців зобов'язує органи влади провінцій його врахувати [10, с. 96].

Отже, можна сказати, що конституційний розвиток Канади був наповнений різноманітними значимими подіями для держави, які, врешті-решт, привели ії одночасно до фактичної незалежності та утвердження власної Конституції у 1982 р. Канадська Конституція є унікальним об'єктом серед Основних законів зарубіжних держав, оскільки це проявляється у її некодифікованості (складається із різних нормативних актів, які діють у державі вже протягом тривалого часу), змішаній формі, впровадженні інституту поправок тощо. Особливої уваги заслуговує Хартія прав і свобод Канади, яка надала низку гарантій прав і свобод громадян, демократичні та особисті права, а найголовніше - принцип рівності, який проявляється у різних формах. Окреме місце в конституційному розвитку Канади посідає Верховний Суд, який став однією із рушійних сил для прийняття власної конституції.

\section{ЛITEPATУРA}

1. Конституционный акт 1867 г. (год 30 и 31 правления Виктории, глава 3, с последующими изменениями) Акт о Союзе Канады, Новой Шотландии и Нью-Брансуика, об их управлении и связанных с этим предметах (27 марта 1867 г.). URL: http://lib.rada.gov.ua/static/ LIBRARY/catalog/law/canada_constitut.html\#\%D0\%9A\%D0\%BE\%D0\%BD\%D1\%81\%D1\%82\%D0\%B8\%D1\%82\%D1\%83\%D1\%86\%D0\%B8 \%D0\%BE\%D0\%BD\%D0\%BD\%D1\%8B\%D0\%B9\%20\%D0\%B0\%D0\%BA\%D1\%82\%201867\%20\%D0\%B3.

2. Russell P.H. Constitutional reform of the Canadian judiciary. Alberta Law Review. 1969. P. 103-129. URL: https://www.albertalawreview. com/index.php/-ALR/article/view/1932/1921.

3. Hogg P.W. A Comment on the Canadian Constitutional Crisis. Yale studies in world public order. 1980. Vol. 6. P. 285-296. URL: https:// digitalcommons.osgoode.-yorku.ca/cgi/viewcontent.cgi?article=2594\&context=scholarly_works.

4. Remillard G., Gall G.L., Makin K.. Supreme CourtofCanada. The Canadianencyclopedia. 2006. URL: https://www.thecanadianencyclopedia. ca/en/article/-supreme-court-of-canada.

5. Leeson H. Developing a Strong Constitution. Canada's history. 2017. URL: https://www.canadashistory.ca/explore/politics-law/ developing-a-strong-constitution.

6. Прокламация о Конституционном акте 1982 г.: 17 апреля 1982 г. URL: http://lib.rada.gov.ua/static/LIBRARY/catalog/law/canada constitut.html\#\%D0\%9A\%D0\%BE\%D0\%BD\%D1\%81\%D1\%82\%D0\%B8\%D1\%82\%D1\%83\%D1\%86\%D0\%B8\%D0\%BE\%D0\%BD\%D0\%BD\% D1\%8B\%D0\%B9\%20\%D0\%B0\%D0\%BA\%D1\%82\%201867\%20\%D0\%B3.

7. The Canadian encyclopedia / Ed. in chief I.H. Marsh. Vol. 1. Edmonton, 1988. P. 497

8. Конституционный акт 1982 г. URL: http://lib.rada.gov.ua/static/LIBRARY/-catalog/law/canada_constitut.html\#\%D0\%9A\%D0\% BE\%D0\%BD\%D1\%81\%D1\%82\%D0\%B8\%D1\%82\%D1\%83\%D1\%86\%D0\%B8\%D0\%BE\%D0\%BD\%D0\%BD\%D1\%8B\%D0\%B9\%20 \%D0\%B0\%D0\%BA\%D1\%82\%201867\%20\%D0\%B3.

9. An Act for Expediting the Decision of Constitutional and Other Provincial Questionts. 1989. URL: https://nslegislature.ca/sites/default/ files/legc/statutes/-constitl.htm.

10. Закоморна К.О. Посібник для підготовки до іспиту з державного (конституційного) права зарубіжних країн. Харків : Право, 2019. $248 \mathrm{c}$. 